THE DIFFERENTIATION OF SHALE TYPES BY ALLOCHTHONOUS AND

\title{
AUTOCHTHONOUS NANNOFOSSILS
}

W. W. Cooper ${ }^{1}$.

ABSTRACT

Examination of the calcareous nannofossils contained in the bit cuttings from portions of three deep wells of the Miocene of South Louisiana allows differentiation of shale types based on the percentage of in-place and reworked forms.

A shale containing greater than $60 \%$ autochthonous nannofossils is identifiable and correlatable for the wells studied. Results are consistent with a benthic foraminiferal zone "pick"

Preliminary results indicate that this method is widely applicable in Tertiary clastic sequences.

${ }^{1}$ Gulf Research and Development Co., Houston, Texas 